\title{
Assessment of the effect of rate and time of application of rice-husk powder as an organic amendment on cowpea (Vigna unguiculata L., walp) inoculated with cowpea mottle virus
}

\author{
Aliyu, T.H, Balogun, O.S and Alade, O.O. \\ Department of Crop Protection, Faculty of Agriculture, University of Ilorin. \\ Email of corresponding Author: aliyutaiyehussein@yahoo.com \\ Tel: 234-(0803)-047-2667
}

\begin{abstract}
A Screen house experiment using potted plants was carried out to assess the effects of time and rate of application of Rice-husk powder as an organic amendment on cowpea (Vigna unguiculata $\mathrm{L}$ Walp) cv. Ife Bimpe, that were mechanically inoculated with Cowpea Mottle Virus $\left(\mathrm{CM}_{\mathrm{e}} \mathrm{V}\right)$. The results showed that the organic amendment was very effective on plants with soils amended with rice-husk powder, as the plants exhibited better yields and productivity. The amended plants also showed considerable less susceptibility to the virus pathogen compared to the non-amended plants. The results of the experiment further showed that the rate and time of application of the Rice-husk powder was a key factor in the ameliorative effect of this organic amendment in the suppression of the viral inoculum. An application rate of $0.50 \mathrm{~kg}$ of Rice-husk powder per $10 \mathrm{~kg}$ of soil two weeks before sowing the cowpea seeds was observed to confer on the plants the highest growth and yield attributes and also the least susceptibility to Cowpea Mottle Virus $\left(\mathrm{CM}_{\mathrm{e}} \mathrm{V}\right)$. On the other hand, cowpea sown on soils amended at a lower rate of $0.125 \mathrm{~kg}$ of Rice-husk powder per $10 \mathrm{~kg}$ of soil two weeks after planting were found to have higher susceptibility to Cowpea Mottle Virus $\left(\mathrm{CM}_{\mathrm{e}} \mathrm{V}\right)$. This is indicative that Rice-husk which is cheap, readily available and environmentally friendly offers a promising prospect in Agriculture both as an Organic amendment and in the control of virus disease in Cowpea if applied at recommended rates and time.
\end{abstract}

Keywords: Rice-husk powder, Rate and Time of Application, Inoculation, Cowpea Mottle virus $\left(\mathrm{CM}_{\mathrm{e}} \mathrm{V}\right)$, Cowpea cv. Ife Bimpe.

\section{INTRODUCTION}

Cowpea is important as a food crop throughout West Africa and especially in the Sudan savanna (Singh and Ntare, 1985). This crop provides food, animal feed and cash for the rural populace in addition to benefits to farmlands via in situ decay of roots residues and ground cover from cowpea's spreading habits. Cowpea grain provides a cheap and nutritious food for relatively poor urban communities (Quin, 1997). Its cultivation is however hampered by several setbacks such as pests and diseases (Ajibade and Amusa, 2001). Most of these pests and diseases thrive best under high relative humidity, which correlates with high rainfall pattern and atmospheric temperature that are found in humid forest of Southern Nigeria (Adegbite and Amusa, 2008).

Among the numerous pathogens affecting cowpea, viruses are known to infect cowpeas either at one stage or throughout the life of the plant. The effects of virus diseases can be devastating, and they are a major constraint to large-scale production (Singh and
Rachie, 1985). Crop losses as a result of diseases caused by plant- infecting viruses, come second only to fungal diseases but plant viruses are much more difficult to control. Nearly 80 virus species occur on arable crops resulting in yield loss worth N700 million per annum (Smart, 2000). Losses due to viral infection of cowpea are between 10\% - 100\% (Rachie, 1985). Cowpea mottle virus $\left(\mathrm{CM}_{\mathrm{e}} \mathrm{V}\right)$ causes mottling or bright yellow mosaic in cowpea. Leaves are distorted, reduced in size and a witches' broom syndrome is common. Yields may be reduced by more than 75\% (Jeyanandarajah \& Brunt, 1993). Indeed, Cowpea yield reductions of more than $75 \%$ have been reported (Shoyinka et al., 1978).

Composted agricultural wastes may be employed in biological control of plant disease (Garrette, 1975). They have since been reported to suppress different types of soil -borne plant diseases (Chen et al, 1988; Janisiewicz and Roitman, 1988; Muhammad, 1998; Muhammed et al., 2001). A soil amendment is any material added to a soil to improve its physical properties, such as water retention, permeability, 
water infiltration, drainage, aeration and structure (Davis and Wilson, 2005). Schucter (1989), found that various types of agricultural/municipal wastes suppress different types of plant diseases by making plants more vigorous and better able to withstand attack.

Rice husk is the natural sheath or productive cover, which forms the cover of rice grains during their growth. Rice husk represents about $20 \%$ by the weight of the rice harvested, about $80 \%$ by weight of the raw husk is made of organic components (Anonymous, 1979). During rice refining processes, the husks are removed from grains. It is of little commercial value and because of its high silicon dioxide contents, it is of little or no use to feed either human or cattle. Incorporation of rice husk into soil mixture was found to affect many crops (Sharma et al., 1988). Muhammed et al. (2001) observed that rice husks composted soil reduced the incidence of wilting of Parkia. biglobosa caused by Fusarium. solani in the range of between $31.4 \%$ to $70.3 \%$.

Though there is abundant information concerning the use of agricultural wastes for soil amendment to improve crop growth and also in the control of fungal and nematode diseases, little is known about the use of these agricultural wastes to control virus diseases in arable crops. For this reason, this study is aimed at assessing the ameliorative effect of rate and time of application of Rice-husk powder as an organic amendment on Cowpea (Vigna unguiculata L., Walp) Cv. Ife Bimpe infected with the Cowpea Mottle Virus.

\section{MATERIALS AND METHODS}

Experimental design and plant propagation: Experiments were conducted in the Department of Crop protection screenhouse of the University of Ilorin, situated in the Southern Guinea Savanna of Nigeria, using potted plants to assess the effect of rate and time of application of Rice-husk powder as an organic amendment on Cowpea (Vigna unguiculata L.,walp) Cv. Ife Bimpe infected with Cowpea Mottle Virus.

The Cowpea cultivar Ife Bimpe used for the experiment was obtained from the Institute of Agricultural Research and Training, Moor plantation Ibadan, Oyo State, Nigeria. Three seeds were sown per 10 -liter $(50 \mathrm{~cm}$ diameter ) plastic pot filled with sandy-loam soil. Prior to potting, however, the soil was steam-sterilised at $121^{\circ} \mathrm{C}$ for 1 hour. The plants were thinned down to two per pot after germination. The three rates of application of rice-husk powder to the soil were at $0.125 \mathrm{~kg} / 10 \mathrm{~kg}$ soil, $0.25 \mathrm{~kg} / 10 \mathrm{~kg}$ soil and $0.50 \mathrm{~kg} / 10 \mathrm{~kg}$ soil, while a non-application rate of
$0 \mathrm{~kg} / 10 \mathrm{~kg}$ soil served as the control. The three different times of application of the amendment to the soil were at two weeks before planting, at planting and at two weeks after planting. This gave a total of 10 treatment combinations, each was replicated three times.

Sourcing of inoculum and inoculation procedure: The Cowpea mottle virus isolate was extracted from infected leaves sourced from the stock of the Plant Virology Laboratory of the International Institute of Tropical Agriculture (IITA) Ibadan, Oyo State Nigeria. The infected leaf sample was extracted by homogenization using pre-cooled mortar and pestle in $0.01 \mathrm{M}$ Sodium phosphate buffer, at $\mathrm{pH} 7.2$ at the rate of $1 \mathrm{~g}$ leaf sample to $10 \mathrm{ml}$ of buffer. Inoculation was done at 7 days after planting by rubbing the inoculum soaked in cotton wool onto the carborundum - dusted $1^{\text {st }}$ and $2^{\text {nd }}$ leaves of the cowpea at the third true leaf stage. The plants and the surroundings were sprayed with cypermethrin at 4 and 6 weeks after planting to further forestall insect infestation.

Data collection and Analysis: Data were collected on weekly basis. Plant height, number of leaves per plant and number of diseased leaves per plant were taken over a period of 8 weeks after inoculation. Yield parameters such as number of pods, dry weight of pods $(\mathrm{g})$ and dry weight of grain $(\mathrm{g})$ were also taken at harvest. The pods were, dried and weighed with the aid of an electronic balance. Threshing was done manually before weighing to get the dry seed weights. The treatment design was a factorial fitted into a randomized complete block design ( RCBD ). All data were therefore, subjected to analysis of variance (ANOVA) having regards for the factorial nature of the treatment design and the significant differences between them were determined at $\mathrm{P}<$ 0.05 using the New Duncan Multiple Range Test.

\section{RESULTS}

Effect on percentage disease severity: Table 1 shows the results of analysis of variance on the combination effect of the treatments on percentage disease severity over 8 weeks. The result shows that the percentage disease severity, as measured by the number of diseased leaves relative to the total number of leaves on any given plant, was for any given week, lowest in cowpea plants amended at the rate of $0.50 \mathrm{~kg} / 10 \mathrm{~kg}$ soil two weeks before planting and highest in plants amended at the rate of $0.125 \mathrm{~kg} / 10 \mathrm{~kg}$ soil two weeks after planting. For instance, at four weeks after infection, the percentage disease severity was $16.2 \%$ in the cowpea plants 
amended at planting at the rate of $0.125 \mathrm{~kg} / 10 \mathrm{~kg}$ soil and lowest $(8.9 \%)$ in plants amended two weeks before planting at the rate of $0.50 \mathrm{~kg} / 10 \mathrm{~kg}$ soil. By the sixth week however there was as a general increase in disease severity for all the treatments. However, plants amended at two weeks before planting at the rate of $0.50 \mathrm{~kg} / 10 \mathrm{~kg}$ soil still had the lowest percentage disease incidence (10.8\%), while the plants amended at two weeks after planting at the rate of $0.25 \mathrm{~kg} / 10 \mathrm{~kg}$ soil had the highest percentage disease incidence (25.6\%). In all situations however, the unammended plants (control), had the significantly highest levels of disease severity compared with any of the other treatments.

Table1 :The combination of rate and time of application of rice-husk powder as an amendment on Percentage disease Severity on cowpea inoculated with $\mathrm{CM}_{\mathrm{e}} \mathrm{V}$

\begin{tabular}{|c|c|c|c|c|}
\hline Treatment Combination & 2wks & 4wks & 6wks & 8wks \\
\hline Control (Inoculated, not amended) & 0 & $30.1 \mathrm{j}$ & $32.1 \mathrm{j}$ & $38.7 \mathrm{~g}$ \\
\hline $2 \mathrm{APX} 0.125 \mathrm{~kg} / 10 \mathrm{~kg}$ & 0 & $25.3 \mathrm{i}$ & $27.6 \mathrm{i}$ & $29.3 g$ \\
\hline $2 \mathrm{BPX} 0.125 \mathrm{~kg} / 10 \mathrm{~kg}$ & 0 & $11.7 \mathrm{c}$ & $14.2 \mathrm{c}$ & $15.1 \mathrm{c}$ \\
\hline AP $\times 0.125 \mathrm{~kg} / 10 \mathrm{~kg}$ & 0 & $16.2 f$ & $19.1 \mathrm{fg}$ & $21.4 \mathrm{e}$ \\
\hline $2 \mathrm{APX} 0.25 \mathrm{~kg} / 10 \mathrm{~kg}$ & 0 & 23.4hi & $25.6 \mathrm{~h}$ & $26.1 f$ \\
\hline $2 \mathrm{BPX} 0.25 \mathrm{~kg} / 10 \mathrm{~kg}$ & 0 & $10.6 \mathrm{bc}$ & $12.4 \mathrm{bc}$ & $13.1 \mathrm{~b}$ \\
\hline AP $\times 0.25 \mathrm{~kg} / 10 \mathrm{~kg}$ & 0 & 15.8ef & $17.9 \mathrm{e}$ & 19.6de \\
\hline $2 \mathrm{APX} 0.50 \mathrm{~kg} / 10 \mathrm{~kg}$ & 0 & $18.3 \mathrm{~g}$ & $21.1 \mathrm{~g}$ & $23.1 \mathrm{f}$ \\
\hline $2 \mathrm{BPX} 0.50 \mathrm{~kg} / 10 \mathrm{~kg}$ & 0 & $8.9 a$ & $10.8 \mathrm{a}$ & $11.1 \mathrm{a}$ \\
\hline AP X $0.50 \mathrm{~kg} / 10 \mathrm{~kg}$ & 0 & 14.3de & 16.4de & $19.3 d$ \\
\hline
\end{tabular}

Means within a column followed by the same letter(s) are not significantly different using the New Duncan multiple Range Test at P>0.05

Effect on Plant height: Table 2 shows the effect of the treatments on heights of infected plants. The analysis of variance showed that at the second week, plant heights were not significantly affected by rate of application of the amendment. However, by the third week post inoculation of the virus, there were significant differences in plant heights through to the $7^{\text {th }}$ week. An amendment with rice-husk powder at the rate of $0.50 \mathrm{~kg} / 10 \mathrm{~kg}$ soil consistently produced the tallest plants from the $2^{\text {nd }}, 3^{\text {rd }}, 4^{\text {th }}$, through to the $8^{\text {th }}$ week post infection. It is apparent that amending the soil with rice-husk two weeks before planting generally had the most desirable effect on plant height as such plants consistently had the tallest heights. An amendment with rice-husk either at planting or at two weeks after planting did not produce any significant differences in heights of infected cowpea plants as they were not significantly different from plants infected in non-amended soil.

Evaluation of the different treatment combinations showed that significant differences existed between them. For example, at two weeks post inoculation, a treatment combination of soil amendment at two weeks before planting at the rate of $0.25 \mathrm{~kg} / 10 \mathrm{~kg}$ soil gave the highest heights of $17.7 \mathrm{~cm}$, while amendment at planting at the rate of $0.50 \mathrm{~kg} / 10 \mathrm{~kg}$ soil gave the lowest heights $(3.8 \mathrm{~cm})$, which was not significantly different from amending 2 weeks after planting at the rate of $0.125 \mathrm{~kg} / 10 \mathrm{~kg}$ soil $(4.8 \mathrm{~cm})$. This trend continued through to the fourth week. By the $5^{\text {th }}$ to the 8th week post infection, however, the treatment combination of amendment at two weeks before planting at the rate of $0.50 \mathrm{~kg} / 10 \mathrm{~kg}$ soil produced the tallest plants.

Effect on number of leaves: Table 3 shows the effect of the treatments on number of leaves. Analysis of the result indicates that it is similar to the pattern observed earlier on as with the plant heights. From the second to the third week after inoculation, there was no significant difference in the number of leaves of the cowpea plants. However, from the $4^{\text {th }}$ to the $8^{\text {th }}$ week post inoculation, an amendment rate of $0.50 \mathrm{~kg} / 10 \mathrm{~kg}$ soil had the significantly highest number of leaves. The application of rice-husk as an amendment two weeks before planting also produced the highest number of leaves in plants on such amended soil. By the $8^{\text {th }}$ week, the combination effect of application two weeks before planting at the rate of $0.50 \mathrm{~kg} / 10 \mathrm{~kg}$ soil produced the highest number of leaves (15), while an application of the amendment two weeks after planting at the rate of $0.125 \mathrm{~kg} / 10 \mathrm{~kg}$ soil had the least number of leaves (13.8). 
Table 2: Effect of rate and time of application of rice husk on plant height of cowpea Inoculated with $\mathrm{Cm}_{\mathrm{e}} \mathrm{V}$

\begin{tabular}{|c|c|c|c|c|c|c|c|}
\hline Rate of Application & $\begin{array}{l}\text { Week2 } \\
\text { (cm) }\end{array}$ & $\begin{array}{l}\text { Week3 } \\
\text { (cm) }\end{array}$ & $\begin{array}{l}\text { Week4 } \\
(\mathrm{cm})\end{array}$ & $\begin{array}{l}\text { Week5 } \\
\text { (cm) }\end{array}$ & $\begin{array}{l}\text { Week6 } \\
\text { (cm) }\end{array}$ & $\begin{array}{l}\text { Week7 } \\
\text { (cm) }\end{array}$ & $\begin{array}{l}\text { Week8 } \\
\text { (cm) }\end{array}$ \\
\hline $\begin{array}{l}\text { Control } \\
\text { amended) }\end{array}$ & $11.5 a$ & $15.1 \mathrm{ab}$ & $15.9 \mathrm{c}$ & $18.6 \mathrm{c}$ & $19.1 d$ & $21.5 d$ & $26.5 b$ \\
\hline $0.125 \mathrm{~kg} / 10 \mathrm{~kg}$ & $11.8 \mathrm{a}$ & $14.2 \mathrm{~b}$ & $15.1 \mathrm{c}$ & $19.8 b$ & $23.4 \mathrm{C}$ & $24.9 b$ & $26.1 b$ \\
\hline $0.250 \mathrm{~kg} / 10 \mathrm{~kg}$ & $13.2 \mathrm{a}$ & $14.3 b$ & $16.7 \mathrm{~b}$ & $19.9 b$ & $22.2 b$ & $23.9 c$ & $26.2 b$ \\
\hline $0.50 \mathrm{~kg} / 10 \mathrm{~kg}$ soil & $11.3 a$ & $15.9 a$ & $17.6 a$ & $21.1 \mathrm{a}$ & $23.7 a$ & $25.6 a$ & $28.3 a$ \\
\hline S.E & 0.8 & 0.52 & 0.48 & 0.94 & 1.0 & 1.02 & 0.74 \\
\hline \multicolumn{8}{|l|}{ Time of Application } \\
\hline 2wksAP & $10.2 b$ & $13.3 b$ & $14.9 b$ & $18.3 b$ & $20.4 b$ & $22.1 b$ & $24.9 b$ \\
\hline $2 \mathrm{wksBP}$ & $15.4 a$ & $18.9 a$ & $20.3 a$ & $23.5 a$ & $25.5 a$ & $28.7 a$ & $31.2 \mathrm{a}$ \\
\hline At planting & $10.9 b$ & $12.4 \mathrm{~b}$ & $13.8 b$ & $17.7 \mathrm{~b}$ & $20.3 b$ & $21.1 b$ & $24.2 b$ \\
\hline S.E & 0.66 & 0.45 & 0.42 & 0.81 & 0.88 & 0.88 & 0.64 \\
\hline \multicolumn{8}{|l|}{ Rate X Time of Application } \\
\hline 2wksAP/0.125kg/10kg & $4.8 d$ & $10.3 \mathrm{~g}$ & $10.7 e$ & $14.6 \mathrm{ef}$ & $20.4 \mathrm{bcd}$ & $21.5 \mathrm{de}$ & $8.2 \mathrm{c}$ \\
\hline $2 \mathrm{wksBP} / 0.125 \mathrm{~kg} / 10 \mathrm{~kg}$ & $16.4 a$ & $18.0 \mathrm{bc}$ & $19.9 c$ & 24.9abc & $25.7 a b$ & $27.4 \mathrm{bc}$ & $10.4 a b$ \\
\hline Atplting $/ 0.125 \mathrm{~kg} / 10 \mathrm{~kg}$ & 14.0abc & 13.7ef & $14.6 \mathrm{~d}$ & 19.8cde & $24.1 \mathrm{abc}$ & $25.8 \mathrm{bcd}$ & 10.9ab \\
\hline $2 \mathrm{wksAP} / 0.25 \mathrm{~kg} / 10 \mathrm{~kg}$ & $10.0 \mathrm{c}$ & $12.4 \mathrm{fg}$ & 13.6de & 17.1cde & $20.3 \mathrm{bcd}$ & 22.0cde & 10.3ab \\
\hline $2 \mathrm{wksBP} / 0.25 \mathrm{~kg} / 10 \mathrm{~kg}$ & $17.7 \mathrm{a}$ & $21.3 a$ & $23.3 a$ & $25.1 \mathrm{ab}$ & $27.5 a$ & $29.3 a b$ & $11.4 a b$ \\
\hline Atplting/ 0.25kg/10kg & $11.8 \mathrm{bc}$ & 13.6ef & $13.2 \mathrm{de}$ & 17.4def & $18.7 \mathrm{~cd}$ & 20.3de & $11.3 a b$ \\
\hline $2 \mathrm{wksAP} / 0.50 \mathrm{~kg} / 10 \mathrm{~kg}$ & $14.6 b$ & 17.6bcd & $20.7 \mathrm{bc}$ & 23.6abc & $24.3 a b c$ & $25.7 \mathrm{bcd}$ & 10.9ab \\
\hline $2 \mathrm{wksBP} / 0.50 \mathrm{~kg} / 10 \mathrm{~kg}$ & $15.6 a b$ & $19.9 a b$ & $21.4 a b$ & $26.6 a$ & $29.4 a$ & $32.9 a$ & $11.1 \mathrm{ab}$ \\
\hline Atplting $/ 0.50 \mathrm{~kg} / 10 \mathrm{~kg}$ & $3.8 d$ & $5.3 \mathrm{~h}$ & $5.9 f$ & $13.2 f$ & $17.3 d$ & $18.0 \mathrm{e}$ & $5.4 \mathrm{c}$ \\
\hline
\end{tabular}

Means within a column ( in each segment) followed by the same letter(s) are not significantly different using the New Duncan Multiple Range Test at $\mathrm{P}>0.05$

Table 3: Effect of rate and time of application of rice husk on number of leaves of cowpea Infected with $\mathrm{Cm}_{\mathrm{e}} \mathrm{V}$

\begin{tabular}{|c|c|c|c|c|c|c|c|}
\hline Rate of Application & Week 2 & Week 3 & Week 4 & Week 5 & Week 6 & Week 7 & Week 8 \\
\hline $\begin{array}{lll}\text { Control } & \text { (Inoculated, } & \text { not } \\
\text { amended) }\end{array}$ & $6.9 a$ & $9.2 \mathrm{a}$ & $11.6 \mathrm{~b}$ & $12.1 \mathrm{a}$ & $14.6 \mathrm{~b}$ & $15.5 b c$ & $16.5 d$ \\
\hline $0.125 \mathrm{~kg} / 10 \mathrm{~kg}$ & $5.8 \mathrm{a}$ & $7.0 \mathrm{a}$ & $9.7 \mathrm{c}$ & $11.1 \mathrm{a}$ & $12.1 \mathrm{C}$ & $15.6 \mathrm{bc}$ & $17.8 \mathrm{~cd}$ \\
\hline $0.250 \mathrm{~kg} / 10 \mathrm{~kg}$ & $7.1 \mathrm{a}$ & $8.5 a$ & $11.0 \mathrm{~b}$ & $13.3 b$ & $14.2 \mathrm{~b}$ & $16.6 \mathrm{~b}$ & $18.6 b c$ \\
\hline $0.50 \mathrm{~kg} / 10 \mathrm{~kg}$ & $5.7 a$ & $6.9 a$ & $13.2 \mathrm{a}$ & $15.2 \mathrm{a}$ & $17.6 a$ & $18.1 \mathrm{a}$ & $19.0 \mathrm{a}$ \\
\hline S.E & 0.45 & 0.80 & 0.62 & 0.88 & 1.31 & 1.16 & 1.10 \\
\hline \multicolumn{8}{|l|}{ Time of Application } \\
\hline $2 \mathrm{wks} A P$ & $6.2 b$ & $7.2 \mathrm{~b}$ & $6.9 \mathrm{~b}$ & $8.6 b$ & $9.6 \mathrm{bc}$ & $11.6 \mathrm{bc}$ & $11.8 \mathrm{bc}$ \\
\hline 2wks BP & $7.6 a$ & $9.5 a$ & $11.1 \mathrm{a}$ & $12.3 a$ & $13.4 \mathrm{a}$ & $14.8 \mathrm{a}$ & $14.9 \mathrm{a}$ \\
\hline At planting & $5.4 \mathrm{c}$ & $6.9 b$ & $7.0 \mathrm{c}$ & $10.1 \mathrm{c}$ & $10.2 \mathrm{bc}$ & $10.8 \mathrm{bc}$ & $10.9 \mathrm{bc}$ \\
\hline S.E & 0.39 & 0.69 & 0.53 & 0.76 & 1.13 & 1.00 & 0.90 \\
\hline \multicolumn{8}{|l|}{ Rate X Time of Application } \\
\hline 2wksAP/0.125kg/10kg & $3.6 \mathrm{bc}$ & $5.2 \mathrm{fg}$ & $8.2 b c$ & $8.8 e f$ & $11.1 d$ & $12.3 f$ & $13.8 \mathrm{~g}$ \\
\hline $2 \mathrm{wksBP} / 0.125 \mathrm{~kg} / 10 \mathrm{~kg}$ & $6.8 \mathrm{a}$ & $7.4 \mathrm{~cd}$ & $10.4 a b$ & $12.7 \mathrm{bc}$ & $16.7 \mathrm{~b}$ & $18.9 \mathrm{~b}$ & $20.0 a b$ \\
\hline At pltng $/ 0.125 \mathrm{~kg} / 10 \mathrm{~kg}$ & $7.1 \mathrm{a}$ & $8.2 \mathrm{c}$ & $10.9 a b$ & $10.9 d$ & $11.8 \mathrm{~d}$ & $14.2 d$ & $16.3 \mathrm{~cd}$ \\
\hline $2 \mathrm{wksAP} \quad 0.25 \mathrm{~kg} / 10 \mathrm{~kg}$ & $5.5 a b c$ & $6.7 \mathrm{ed}$ & $10.3 a b$ & $11.4 \mathrm{~cd}$ & $13.4 \mathrm{c}$ & $14.5 d$ & 14.9ef \\
\hline $2 \mathrm{wksBP} / 0.25 \mathrm{~kg} / 10 \mathrm{~kg}$ & $8.0 \mathrm{a}$ & $10.5 a$ & $11.4 \mathrm{ab}$ & $12.6 \mathrm{bc}$ & $13.8 \mathrm{c}$ & $16.1 \mathrm{c}$ & $17.9 \mathrm{c}$ \\
\hline Atpltng / 0.25kg/10kg & $7.7 a$ & $8.6 c$ & $11.3 a b$ & $11.7 \mathrm{~cd}$ & $11.9 \mathrm{~d}$ & 13.1ef & $15.6 \mathrm{e}$ \\
\hline $2 \mathrm{wksAP} / 0.50 \mathrm{~kg} / 10 \mathrm{~kg}$ & $5.7 a b c$ & $8.7 c$ & $10.9 a b$ & $11.3 \mathrm{~cd}$ & $11.7 \mathrm{~d}$ & $13.7 \mathrm{ef}$ & $15.2 \mathrm{e}$ \\
\hline $2 \mathrm{wksBP} / 0.50 \mathrm{~kg} / 10 \mathrm{~kg}$ & $8.1 \mathrm{a}$ & $9.7 b$ & $11.1 \mathrm{ab}$ & $16.2 a$ & $19.9 a$ & $21.6 a$ & $23.4 \mathrm{a}$ \\
\hline Atpltng $/ 0.50 \mathrm{~kg} / 10 \mathrm{~kg} \mathrm{~s}$ & $3.4 \mathrm{c}$ & $4.9 \mathrm{~g}$ & $5.4 \mathrm{C}$ & $7.4 f$ & $10.5 \mathrm{e}$ & $12.3 f$ & $14.9 \mathrm{ef}$ \\
\hline
\end{tabular}

Means within a column (in each segment) followed by the same letter(s) are not significantly different using the New Duncan Multiple Range Test at $P>0.05$ 
Effect on yield attributes: Table 4 shows the effect on yield of the combination of rate and time of application of rice-husk powder as an amendment on cowpea infected with $\mathrm{CM}_{\mathrm{e}} \mathrm{V}$. As with the other parameters, the analysis of the variance shows that the yield attributes in plants amended with rice-husk at the rate of $0.50 \mathrm{~kg} / 10 \mathrm{~kg}$ soil two weeks before planting was the highest compared to the other treatments. Total number of pods per plant was highest $(22.6 \mathrm{~g})$, in plants amended at the rate of $0.50 \mathrm{~kg} / 10 \mathrm{~kg}$ soil two weeks before planting and lowest $(9.0 \mathrm{~g})$ in plants amended at planting at the rate of $0.50 \mathrm{~kg} / 10 \mathrm{~kg}$ soil. The grain weights also followed the same trend with plants amended at two weeks before planting at the rate of $0.50 \mathrm{~kg} / 10 \mathrm{~kg}$ soil having the significantly highest weights of $12.8 \mathrm{~g}$, and plants amended at planting at the rate of $0.50 \mathrm{~kg} / 10 \mathrm{~kg}$ soil having grain weights of $2.5 \mathrm{~g}$.

Table4: The combination of rate and time of application of rice-husk powder as an amendment on Yield attributes of cowpea infected with $\mathrm{CM}_{\mathrm{e}} \mathrm{V}$

\begin{tabular}{|c|c|c|c|}
\hline Treatment Combination & $\begin{array}{l}\text { Total no of pods } \\
\text { per plant }\end{array}$ & $\begin{array}{l}\text { Wt of pods per } \\
\text { (g) }\end{array}$ & Weight of grain(g) \\
\hline Control (Inoculated, not amended) & $8.2 \mathrm{e}$ & $8.8 \mathrm{e}$ & $3.5 d$ \\
\hline $2 \mathrm{APX} 0.125 \mathrm{~kg} / 10 \mathrm{~kg}$ & 6.2ef & $7.8 \mathrm{e}$ & $4.0 d$ \\
\hline $2 B P \times 0.125 \mathrm{~kg} / 10 \mathrm{~kg}$ & $17.4 \mathrm{~b}$ & $12.8 \mathrm{c}$ & $9.0 \mathrm{c}$ \\
\hline $\mathrm{AP} \times 0.125 \mathrm{~kg} / 10 \mathrm{~kg}$ & $14.0 \mathrm{c}$ & $8.0 \mathrm{e}$ & $3.5 d$ \\
\hline $2 \mathrm{APX} 0.25 \mathrm{~kg} / 10 \mathrm{~kg}$ & $13.4 \mathrm{~cd}$ & $8.3 e$ & $3.3 d$ \\
\hline $2 \mathrm{BP} \times 0.25 \mathrm{~kg} / 10 \mathrm{~kg}$ & $16.6 \mathrm{~b}$ & $16.8 b$ & $11.3 b$ \\
\hline AP $\times 0.25 \mathrm{~kg} / 10 \mathrm{~kg}$ & $12.0 \mathrm{~cd}$ & $9.5 e$ & $3.5 d$ \\
\hline $2 \mathrm{APX} 0.50 \mathrm{~kg} / 10 \mathrm{~kg}$ & $5.4 \mathrm{~g}$ & $8.5 e$ & $3.0 d$ \\
\hline 2BPX0.50kg/10kg & $22.6 a$ & $18.0 \mathrm{a}$ & $12.8 \mathrm{a}$ \\
\hline AP $\times 0.50 \mathrm{~kg} / 10 \mathrm{~kg}$ & $9.4 \mathrm{e}$ & 10.3de & $2.5 d$ \\
\hline
\end{tabular}

Means within a column followed by the same letter(s) are not significantly different using the New Duncan multiple Range Test at $\mathrm{P}>0.05$

DISCUSSION: The application of organic amendments for the control of plant diseases has been repeatedly explored as an environmentally sensible alternative to the use of synthetic pesticides. The widespread adoption of such an approach has however, been limited by variability in efficacy of such treatments, which in turn has defied resolution due to a general absence of knowledge concerning the mechanisms of disease suppression imparted by these amendments (Cohen et al., 2005).

Rice- husk has variously been used both as an amendment to improve crop yield and also in the control of pathogens particularly fungi, nematodes and bacteria. It is apparent from this study that rice-husk, ground into powder could also be used in the control of virus diseases in cowpea. Virus infected cowpea plants that were not amended with rice-husk powder, had growth and yield parameters that were significantly lower than the infected cowpea plants that were amended with ricehusk powder. This is an indication that rice-husk powder could indeed be used as a potent soil amendment to improve the growth and productivity and the suppression of viral diseases in infected cowpea plants.
The mechanism for this control is assumed to be the impartation of competitive advantage to plants growing on the amended soils compared to those on non amended soils. Such plants grew more luxuriantly thereby conferring more photosynthetic advantage. On the other side, plants in non amended soils probably suffered reduced photosynthetic activity occasioned by reduced number of leaves. This reduced photosynthesis is marked during the period of rapid virus increase (Bedrock and Mathews, 1973). Green and Kim (1991) had reported that viruses altered the metabolism of plant cells causing the plants to grow abnormally; a condition that causes both decreased yield and visible symptoms. Reduced photosynthesis due to low chlorophyll levels associated with increased viral symptoms had also been linked to low growth and yield attributes in tomato infected by tomato mosaic virus singly and in combination with Potato virus $X$ (Balogun, 1999).

An amendment with rice-husk powder at the rate of $0.50 \mathrm{~kg} / 10 \mathrm{~kg}$ soil was also found in this study to be the most suitable amongst the other treatments in the control of Cowpea mottle virus in cowpea. Ugwoke and Onyishi (2009), had reported that poultry manure and Mycorrhizae when well managed can be a valuable Agricultural tool in the management of Okra Mosaic Virus, and that an application of up to 40 tons/ha of 
poultry manure combined with mycorrhizae increases yield. The early incorporation of the amendment at two weeks before planting, which was found to be the most effective in this study, is attributable to its ability to confer on the plants added nutrients and a longer release period. This finding is in agreement with Mbagwu (1988), who stated that organic manures have a slow and long term release of nutrients and have a tendency for sustainable production.

\section{CONCLUSIONS:}

The study shows that rice-husk powder applied to infected cowpea plants as a soil amendment two weeks before planting at the rate of $0.50 \mathrm{~kg} / 10 \mathrm{~kg}$ soil played a significant role in suppressing the pathogenic effects of the virus. It could therefore be used as an effective cultural measure in the management of virus diseases in cowpea. However, further studies on the mechanism by which rice-husk powder achieved the ability to suppress the virus infection is warranted.

Abbreviations : $\mathrm{CM}_{\mathrm{e}} \mathrm{V}$ : Cowpea mottle virus. AP: After planting. BP: Before planting. AT planting: At planting.

\section{ACKNOWLEDGEMENT:}

The authors will like to express their sincere appreciation to Dr. Lava Kumar of the plant virology unit of the International Institute of Tropical Agriculture (IITA) Ibadan, Oyo State - Nigeria, for the provision of the Cowpea mottle virus isolate used in the course of this study.

\section{REFERENCES}

Adegbite, A.A and Amusa , N.A(2008):African Journal of Biotechnology Vol. 7 (25), pp. 4706-4712, 29 December 2008

Ajibade S.R and Amusa NA (2001). Effects of Fungal diseases on some cowpea lines in the humid environment of Southwestern Niger. J. Sust. Agric. Environ. 3: 246-253.

Anonymons (1979). Rice situation, Economics and cooperative service. US Department of Agriculture, Washington, D.C.20250.

Balogun, O.S. (1999) Physiological responses in tomato under mixed infections with Potato $X$ potexvirus and Tobacco mosaic tobamovirus. CentrePoint Science Edition 9: 7080.

Chen Y, Inbar Y, Hadar Y (1988). Composted Agricultural wastes as potting media for ornamental plants. Soil Sci.145-298.

Cohena, M.F., Yamasakib, H., and Mazzolaa, M (2005). Soil Biology \& Biochemistry 37 (2005) 1215-1227 .

Davis J.G and Wilson CR (2005). Choosing a Soil Amendment. Colorado State University Cooperative Extension Horticulture.7: 235.
Garrett S.N (1975). Pathogenic Root-infecting Fungi. Cambridge Univ. Press: Cambridge, p 257.

Green, S. K. and Kim, J. S. (1991). Characteristics and control of viruses infecting peppers.Technical Bulletin No. 18. Asian Vegetable Research and Development Centre, Taipei, Taiwan

Janisiewicz, W.J and Roitman J (1988). Biological control of blue mold and gray mold on apple and pear with Pseudomonas cepacia. Phytopathology 78: 1697.

Jeyanandarajah, P. and Brunt, A.A. (1993). The natural occurrence, transmission, properties and possible affinities of cowpea mild mottle virus. Journal of Phytopathology 137, 148-156.

Mbagwu, J. S. C. (1988). Sub-soil productivity of an Ultisoil in Nigeria as effected by

organic Waste and inorganic fertilizer Amendments. Soil Sci. 140(6):436-441.

Muhammad, S (1998). Effects of Soil Amendments with Ricehusks on Fusarium wilt of pepper Capsicum annum. The Beam: J. Arts Sci. 4: 108-112.

Muhammad, S. Suberu H.A, Amusa N.A, and Agaji M.D (2001). The Effect Of Soil Amendment with Sawdust and Rice Husks on the growth and incidence of seedling blight Of Tamarrindus indica Linn caused by by Macrophomina phaseolina and Rhizoctonia solani. Moor J. Agric. Res. 2: 40-46.

Quin, FM (1997). Importance of Cowpea in Advances in Cowpea Research. B.B. Singh, K.E. Dashiell, D.R. Mohan Raj and L.E.N. Jackai (Eds.), Pg. X-Xii. Printed by Colcorcraft, Hong Kong, p. 375

Rachie, K.O (1985). Introduction. In cowpea research, production and utilization. Edited by : Singh SR. Rachie KO, John Wiley and sons, Chichester UK., 1985.

Schueter, C. (1989). Antiphytopathogenic properties of biogenic wastes compost. Agric. Ecosystem Environ. 27: 477-482.

Sharma, S. K.; C. M. Sharma, and I. S. Shakor (1988). Effect of industrial organic wastes and lantana incorporation on soil properties and yield of rice.Indian J. of Agronomy. 33: 225-226.

Shoyinka, S.A., Bozarth, R.F., Rees, J., and Rossel, H.W(1978).Cowpea mottle virus: a seed borne virus with distinctive properties infecting cowpea in Nigeria. Phytopathology 68 (5), 693-699.

Singh, B.B. and Ntare, B.R 1985. Development of improved cowpea varieties in Africa. In. S.R. Singh and K.O. Rachie (eds). Cowpea Research, Production and Utilization. John Willey and Sons. pp $105-115$.

Singh, S.R and Rachie, K.O (1985).Cowpea Research, Production and Utilisation. Edited by S.R. Singh and K.O. Rachie. 